\title{
Accuracy Determining Anthropometric Norms in Young Adults using Discriminant Functional Analysis \\ Vasavada $D^{1}$, Ojha $\mathbf{M}^{1^{*}}$, Phulari RGS ${ }^{1}$, Arora $\mathbf{P}^{2}$, Rathod $\mathbf{Y}^{1}$, Rathod $\mathbf{R}^{1}$, and Desai $\mathbf{H}^{2}$ \\ ${ }^{1}$ Department of Oral, Maxillofacial Pathology and Microbiology, Manubhai Patel Dental College and Hospital, India \\ ${ }^{2}$ Department of Orthodontics and Orthopaedics, Manubhai Patel Dental College and Hospital, India
}

"Corresponding author: Mehul Ojha, Department of Oral, Maxillofacial Pathology and Microbiology, Manubhai Patel Dental College and Hospital, India, Tel: 9638394210; E-mail: mehulojha7@gmail.com

Received date: June 6, 2018; Accepted date: June 30, 2018; Published date: July 5, 2018

Copyright: 2018 Vasavada D et al. This is an open-access article distributed under the terms of the Creative Commons Attribution License, which permits unrestricted use, distribution, and reproduction in any medium, provided the original author and source are credited.

\begin{abstract}
Scientific standards have been set up for some ethnic and racial gatherings in numerous examinations. Standard for every ethnic gathering are basic for measurable drug. There are contrasts among races and ethnic gatherings and standard have been produced for specific race and gathering. Data on cephalometric standards for a populace has colossal incentive in legal dentistry. Cephalometric guidelines permit recognizable proof of race and sexual orientation of casualties utilizing straightforward estimations. The utilization of morphological highlights of the skull and mandible is a typical approach utilized by anthropologists in sex assurance.
\end{abstract}

Keywords: Forensic odontology; Anthropology; Cephalometric landmarks; Discriminant functional analysis; Gender determination

\section{Introduction}

Anthropology is the study of humans, from past to present and forensic anthropology is the application of this science in a legal setting and frequently used when victim's remains are in the advanced stages of decomposition [1]. A forensic anthropologist usually assist in the identification of deceased individuals whose remains are decomposed, burned, mutilated or otherwise unrecognizable. Using physical markers present on an individual's skeleton, a forensic anthropologist can potentially determine a victim's age, sex, stature, and ancestry [2].

Forensic norms have been set up for various ethnic and racial groups and standard norms for each ethnic group are critical for forensic medicine [3]. There are differences among races and ethnic groups and standard norms have been developed for particular race and group. Studies to identify the differences in facial features of various ethnic groups including Indians, Africans, African-Americans, Brazilians, Japanese, Puerto Ricans, Saudi Arabians, Turkish, Hungarians and Russians have been carried out in the past [4].

Information on cephalometric norms for a population has tremendous value in forensic dentistry. Cephalometric standards allow identification of race and gender of victims using simple measurements [4]. The use of morphological features of the skull and mandible is a common approach used by anthropologists for sex determination [5].

Amongst the very few studies carried out on craniofacial anthropology, Farkas et al. has given an extensive data on Indian adults where 11 measurements were recorded in craniofacial complex [6,7]. The present study was carried out with an objective to establish the craniofacial anthropometric norms of the young Indian adults, to set population-specific standards which can be a useful tool in forensic odontology and to test the validity of sex determination using lateral cephalograms.

\section{Methods}

The study group consisted of a sample of 203 young Indian adults (100 males, 103 females) between the age group of 17-25 years who visited department of oral medicine and Radiology-Manubhai Patel dental college, Vadodara. The study was approved by the Institutional ethics committee.

The patients visiting the outpatient department, who had normal occlusion, were considered for the study and lateral cephalometric radiographs were taken with patients consent. The participants were generally healthy and exhibited no craniofacial abnormalities either acquired through any accidents or other forms of trauma, congenital or developmental discrepancies and had no history of plastic or reconstructive surgery.

Lateral cephalograms were taken from X-Mind Pano D+Setelac unit and was obtained in a standard position with the teeth in centric occlusion and lips relaxed. Standardized mandibular orientation and exposure parameters ( 8 to 20 seconds exposure time, voltage $57-85 \mathrm{kv}$ and current $10 \mathrm{~mA}$ ) were used. The Onyx Ceph (version 4, 2016) radiographic analysis software was used to trace the lateral cephalometric radiographs with prior calibration done before every tracing.

Eleven measurements were taken with the help of ruler icon and angle icon in onyx tracing software and values were tabulated (Table 1). Showing a lateral cephalogram of the patient (Figure 1), showing all traced cephalometric parameters on the radiograph. Each radiograph was traced and cephalometric landmarks were determined with the help of a good viewer (Figures $2 \mathrm{a}$ and $2 \mathrm{~b}$ ). 
Citation: Vasavada D, Ojha M, Phulari RGS, Arora P, Rathod Y, Rathod R, Desai H (2018) Accuracy Determining Anthropometric Norms in Young Adults using Discriminant Functional Analysis. J Forensic Res 9: 421. doi:10.4172/2157-7145.1000421

Page 2 of 5

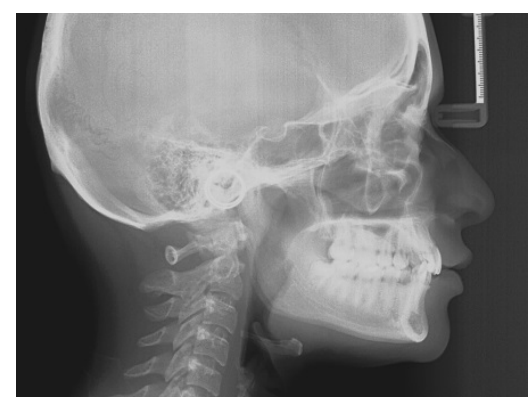

Figure 1: Showing lateral cephalogram of a patient.

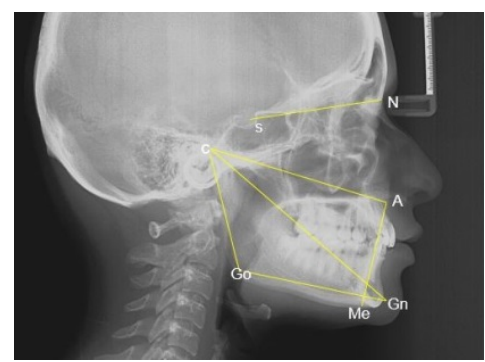

Figures 2a: Showing all traced cephalometric parameters on the radiograph.

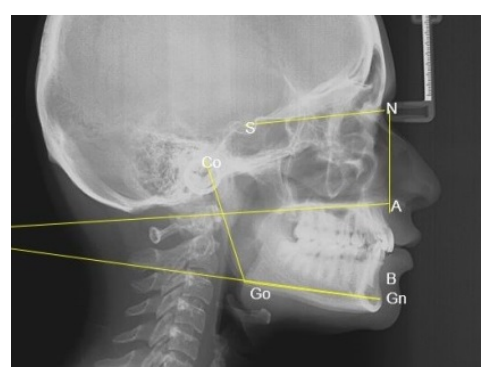

Figure 2b: Each radiograph was traced and cephalometric landmarks were determined.

\begin{tabular}{|c|c|c|}
\hline SI No. & Parameters & Landmarks \\
\hline 1 & Effective Maxillary length & Co-Point A \\
\hline 2 & Mandibular body length & Go-Gn \\
\hline 3 & Ramus Height & Co-Go \\
\hline 4 & Effective Mandibular length & Co-Gn \\
\hline 5 & Lower facial height & ANS-Me \\
\hline 6 & SNA angle & S-Sella, N-Nasion and A Point angle \\
\hline 7 & SNB angle & S-Sella, N-Nasion and B Point angle \\
\hline 8 & ANB angle & The angle between Point A, Nasion and Point B \\
\hline 9 & Anterior Cranial Base & $\mathrm{N}-\mathrm{Se}$ \\
\hline 10 & Palatal Mandibular angle & Angle between palatal plane(ANS-PNS) and Mandibular Plane(Go-Gn) \\
\hline 11 & Gonial angle & Co-Go-Me. Angle between condylion, gonion and menton. \\
\hline
\end{tabular}

Table 1: List of 11 Cephalometric Parameters and Landmarks measured in the study.

\section{Statistical Analysis}

Data was entered in MS Excel and analyzed using statistical software "R 2.15.2-India". Descriptive statistics were obtained in form of mean, Std. Deviation and correlation coefficient. Independent t-test was applied to check mean difference of various parameter values between male and female respondents (Table 2).

\section{Results}


Citation: Vasavada D, Ojha M, Phulari RGS, Arora P, Rathod Y, Rathod R, Desai H (2018) Accuracy Determining Anthropometric Norms in Young Adults using Discriminant Functional Analysis. J Forensic Res 9: 421. doi:10.4172/2157-7145.1000421

Page 3 of 5

\begin{tabular}{|c|c|c|c|c|c|c|c|c|}
\hline SI No. & & Sex & $\mathbf{N}$ & Mean & Std. Deviation & Mean difference & t-value & p-value \\
\hline \multirow[b]{2}{*}{1} & \multirow[b]{2}{*}{ Effective Maxillary Length (mm) } & Male & 100 & 96.25 & 4.412 & 5.404 & 5.821 & 0.000 \\
\hline & & Female & 103 & 90.85 & 4.860 & & & \\
\hline \multirow[b]{2}{*}{2} & \multirow[b]{2}{*}{ Mandibular Body Length $(\mathrm{mm})$} & Male & 100 & 78.45 & 4.145 & 6.344 & 7.849 & 0.000 \\
\hline & & Female & 103 & 72.10 & 3.935 & & & \\
\hline \multirow[b]{2}{*}{3} & \multirow[b]{2}{*}{ Ramus Height (mm) } & Male & 100 & 62.52 & 4.078 & 6.498 & 6.595 & 0.000 \\
\hline & & Female & 103 & 56.02 & 5.649 & & & \\
\hline \multirow[b]{2}{*}{4} & \multirow[b]{2}{*}{ Effective Mandibular Length (mm) } & Male & 100 & 119.73 & 6.155 & 8.834 & 7.360 & 0.000 \\
\hline & & Female & 103 & 110.89 & 5.844 & & & \\
\hline \multirow[b]{2}{*}{5} & \multirow[b]{2}{*}{ Lower facial height (mm) } & Male & 100 & 56.67 & 5.411 & 3.788 & 4.108 & 0.000 \\
\hline & & Female & 103 & 52.88 & 3.637 & & & \\
\hline \multirow[b]{2}{*}{6} & \multirow[b]{2}{*}{ SNA (Angle) } & Male & 100 & 84.32 & 2.140 & -0.422 & -0.838 & 0.404 \\
\hline & & Female & 103 & 84.74 & 2.847 & & & \\
\hline \multirow[b]{2}{*}{7} & \multirow[b]{2}{*}{ SNB (Angle) } & Male & 100 & 82.99 & 2.789 & 1.366 & 2.515 & 0.014 \\
\hline & & Female & 103 & 81.63 & 2.642 & & & \\
\hline \multirow[b]{2}{*}{8} & \multirow[b]{2}{*}{ ANB (Angle) } & Male & 100 & 1.37 & 2.409 & -1.788 & -4.157 & 0.000 \\
\hline & & Female & 103 & 3.16 & 1.856 & & & \\
\hline \multirow[b]{2}{*}{9} & \multirow[b]{2}{*}{ Anterior Cranial Base $(\mathrm{mm})$} & Male & 100 & 73.18 & 2.137 & 5.604 & 8.804 & 0.000 \\
\hline & & Female & 103 & 67.58 & 3.962 & & & \\
\hline \multirow[b]{2}{*}{10} & \multirow[b]{2}{*}{ Pal-Man (Angle) } & Male & 100 & 16.67 & 3.080 & -0.196 & -0.351 & 0.726 \\
\hline & & Female & 103 & 16.87 & 2.474 & & & \\
\hline \multirow[b]{2}{*}{11} & \multirow[b]{2}{*}{ Gonial angle } & Male & 100 & 117.86 & 14.746 & -6.068 & -2.768 & 0.007 \\
\hline & & Female & 103 & 123.93 & 4.786 & & & \\
\hline
\end{tabular}

Table 2: Showing the descriptive statistics for the 11 cephalometric measurements among the male and female groups.

Discriminant Analysis was run to discriminate male and female respondents using selected angles, lengths and gender determination was done using this method. Calculations of 11 cephalometric measurements were performed are given in Table 2. Descriptive statistics including means, standard deviations, and coefficient of variations were calculated for all the variables. The values derived were compared between both the sexes using Independent $t$ test. Significance was set at $\mathrm{p}<0.05$ value. The fitted model is significant with Wilk's lambda of 0.510 and p-value $<0.001$. Standardized canonical discriminant function coefficients are given in Table 3. The functions at group centroids (cut offs) to determine gender is \pm 0.970 . Thus if the discriminant function shows value nearer to 0.970 , the person can be predicated as a "Male" and if the value is nearer to -0.970 , that can be predicated as "Female".

\begin{tabular}{|l|l|}
\hline & Function coefficient \\
\hline Go-Gn (Mandibular Body Length) mm & 1.200 \\
\hline
\end{tabular}

\begin{tabular}{|l|l|}
\hline Co-Go (Ramus Height) $\mathrm{mm}$ & 0.903 \\
\hline Co-Gn (Mandibular Length) in mm & -0.807 \\
\hline Lower facial height in mm & -0.068 \\
\hline Pal-Man (Angle) & 0.028 \\
\hline Gonial (angle) & -0.202 \\
\hline
\end{tabular}

Table 3: Standardized Canonical Discriminant Function Coefficients of 6 cephalometric parameters measured.

\section{Discussion}

To our knowledge, this is the one of the few studies using cephalometric norms in young adult Indian population. The results of this study on a sample of adult Indian population indicate that certain 
linear and angular measurements are significantly different between adult males and females in India.

Sex determination is an important tool in forensic odontology especially in mass disaster cases where victims' bodies are mutilated beyond recognition. Identification techniques like facial reconstruction would not be possible unless sex is correctly determined. Various methods of sex determination have been reported like studying the morphology of skull and mandible, cephalometric analysis using dental X-rays, DNA analysis of teeth etc [8].

Sex determination depends on the experience of the investigator; Inexperienced workers are likely to make inaccurate assessment of sex based using visual methods [3]. The technique of discriminant function analysis overcomes some of the problems inherent in subjective methods of sexing skulls, providing a relatively simple, objective means of sexing material with a calculable reliability [3]. Discriminant function for the determination of sex has not been derived specifically for the Indian population.

In the present study, 11 cephalometric measurements were evaluated for gender prediction using discriminant function analysis out of which 6 of the measurement provided accurate sex discrimination in the subjects of known sex. In the present study, men showed significantly larger measurements for 5 linear skeletal parameters namely effective maxillary length (Co-Pt A), Mandibular body length (Go-Gn), ramus height(Co-Go), effective mandibular length(Co-Gn) and lower facial height (ANS-Me) whereas angular measurements namely SNA, ANB and gonial angle were greater in females as compared to males.

Williams and Rogers [8] got $96 \%$ success in determining the sex using different features of the skull and the mandible, with constant six traits: mastoid, supraorbital ridge, size and architecture of skull, zygomatic extension, nasal aperture and mandibular gonial angle. This indicates that craniofacial morphology can be used to determine sex of skeletal specimen with a high degree of precision.

According to Vanrell [9], the differential diagnosis of the sex by the analysis of the morphological characteristics of the skull and mandible has $77 \%$ success rate, while the analysis on metric traits of the skull in distinguishing the sex exceed $90 \%$ accuracy [9]. According to discriminant analysis, that the bi-zygomatic distance presented the greatest sexual dimorphism, corroborating the results of other researchers [10-15].

In establishing the identity of sex from a defleshed skull, lateral cephalograms and posteroanterior view radiographs assume a predominant role, as they provide architectural and morphological details of the skull, thereby revealing additional characteristics and multiple points for comparison [16]. Various workers have claimed that skull radiographs are a reliable method of sex determination with accuracy up to $80 \%-100 \%$ [17].

In the present study, 11 cephalometric measurements were used in discriminant function analysis out of which gender determination was dependent on Go-Gn, Co-Go, Co-Gn and lower facial height. $94 \%$ males and $78 \%$ females were correctly identified by given function. Hence the accuracy of the given model comes out to be $86 \%$ to predict gender of the person.

Hsiao et al. [17] attempted to develop a new method to determine sex from the skull with lateral radiographic cephalometry and discriminant function analysis. With discriminant function created from 18 cephalometric variables the sex was determined with $100 \%$ accuracy in a random sample of 100 Taiwanese adults.

In a study by Patil and Mody [18], with discriminant function derived by using 10 cephalometric variables, in $99 \%$ of cases sex could be determined correctly. Veyre-Goulet et al. showed that sex could be determined with $95.6 \%$ accuracy in a sample of 114 adult dry skulls of European population using discriminant function derived from the cephalometric measurements [18]. Thus, discriminant function analysis seems suitable, but the most indicative variables differ relative to the ethnic population concerned.

Our results will therefore be useful among both genders in forensic dentistry for identification purposes. In future, this discriminant method should be tested on greater populations with a diverse age group to confirm its reliability. The present study could not determine high degree of accuracy nearing $100 \%$ probably due to relatively smaller sample size. There lies a scope for future studies involving larger samples and greater number of cephalometric parameters [19].

\section{Conclusion}

From our study we conclude that Cephalometric landmarks are useful aid in forensic dentistry for identification purposes. Very few studies have been administered in other population groups and no study in Indian population group has been conducted using eleven parameters, hence this study can be first of its kind which can give cephalometric norms for Indian population. Correlation between Indian Cephalometric norms and its forensic implications will help in identification of humans in mass disasters.

\section{References}

1. Byers S (2010) Introduction to forensic anthropology, 4th edn, Routledge, UK.

2. Stanojevich V (2012) The role of a forensic anthropologist in a death investigation. J Forensic Res 3: 154.

3. Mathur RU, Mahajan AM, Dandekar RC, Patil RB (2014) Determination of sex using discriminant function analysis in young adults of nashik: A lateral cephalometric study. J Adv Med Dent Scie 2: 21-25.

4. Ayoub F, Yehia M, Rizk A, Al-Tanni M, Abi- Farah A et al. (2008) Forensic norms of female and male lebanese adults. J Forensic Odontolstomatol 26: 18-23.

5. Sweet D (2001) Why a dentist for identification? Dent Clin North Am 45: 237-251.

6. Ngeow WC, Aljunid ST (2009) Craniofacial anthropometric norms of malaysian indians. Indian J Dent Res 20: 313-319.

7. Farkas LG, Katic MJ, Forrest CR, Alt KW, Bagic I et al. (2005) International anthropometric study of facial morphology in various ethnic groups/races. J Craniofac Surg 16: 615-646.

8. Rajendran A, Sivapathasundharam B (2009) Shafer's textbook of oral pathology, 6th edn, Elsevier, India, pp: 871-875.

9. Vanrell (2009) JP Odontologia legal e antropologia forense. 2nd edn, Guanabara Koogan publisher, Brazil.

10. Hemant M, Vidya M, Nandaprasad, Karkera BV (2008) Sex determination using dental tissue. MedLegal Update 8: 13-15.

11. Krogman WM, Iscan MY (1962) The human skeleton in forensic medicine, 2nd edn, Charles C Thomas Publisher, USA.

12. Steyn M, Iscan MY (1998) Sexual dimorphism in the crania and mandibles of south african whites. Forensic Sci Int 98: 9-16.

13. Monticelli F, Graw M (2008) Investigation on the reliability of determining sex from the human zygomaticum. Forensic Med Sci Pathol 4: 181-186. 
Citation: Vasavada D, Ojha M, Phulari RGS, Arora P, Rathod Y, Rathod R, Desai H (2018) Accuracy Determining Anthropometric Norms in Young Adults using Discriminant Functional Analysis. J Forensic Res 9: 421. doi:10.4172/2157-7145.1000421

Page 5 of 5

14. Kranioti EF, Iscan MY, Michalodimitrakis M (2008) Craniometric analysis of the modern cretan population. Forensic Sci Int 180: 110e1-110e5.

15. Naikmasur VG, Shrivastava R, Mutalik S (2010) Determination of sex in south indians and immigrant tibetans from cephalometric analysis and discriminant functions. Forensic Sci Int 197: 122e1-122e6.

16. Sivagami AV, Rao AR, Vaishney U (2000) A simple and cost effective method for preparing DNA from thehard tooth tissue and its use in PCR amplification of amelogenin gene segment for sex determination in indian population. Forensic Sci Int 110: 107-115.
17. Biggerstaff RH (1977) Craniofacial characteristics as determinants of age, sex and race in forensic dentistry. Dent Clin North Am 21: 85-97.

18. Hsiao TH, Tsai SM, Chou ST, Pan JY, Tseng YC et al. (2010) Sex determination using discriminant function analysis in children and adolescents: A lateral cephalometric study. Int J Legal Med 124: 155-160.

19. Patil KR, Mody RN (2005) Determination of sex by discriminant function analysis and stature by regression analysis: A lateral cephalometric study. Forensic Sci Int 147: 175-180. 